\title{
Monetary Approach to the Balance of Payments: A Moroccan Case Study
}

\author{
Mariam Elhaddadi ${ }^{1} \&$ Mohamed Karim $^{1}$ \\ ${ }^{1}$ EREMEPP, University of Mohammed V, Rabat, Morocco \\ Correspondence: Mohamed Karim, University of Mohammed V, Rabat, Morocco.
}

Received: August 1, 2017

Accepted: August 30, $2017 \quad$ Available online: August 31, 2017

doi:10.11114/aef.v4i5.2629

URL: https://doi.org/10.11114/aef.v4i5.2629

\begin{abstract}
The IMF has always promoted the theories of external adjustment. These theories were inspired by the work of J.Polak who first came up with the Monetary Approach to the Balance of Payments in 1957. In this approach, the balance of payments imbalances are related to excess: the model allows calculating a compatible amount of credit with a fixed target of external reserves. It is based on two assumptions: the constant money demand related to the income and the exogenous nature of the money supply resulting to an autonomous decision of the monetary authorities which fixes the internal component of currency level. An external imbalance is therefore only the symptom of a deeper evil, of monetary origin.

In this paper, the Polak model will be applied on the variables of the Moroccan economy and study the results generated from the adjustment through the monetary balance of payments approach on its deficit.
\end{abstract}

Keywords: balance of payments, deficit, export

\section{Introduction}

In the 1980s and 1990s, the economy of many countries was gradually opening to the rest of the world. This phenomenon was amplified in 2000 with the arrival of new countries on the international scene such as Brazil, Russia, India and China (BRIC).

Thus, globalization came along with a very significant increase of the global production as well as the economic and financial exchanges between countries. However, flow and stock imbalances arised among different geographical areas. As a result, the international monetary and financial stability was shaken. So it is safe to say that economic, financial and monetary phenomena are closely intertwined.In order to achieve a better understanding of the international imbalances, it is necessary to study macroeconomic conditions and macro financial balance in an open economy. The interrelationships between the macroeconomics and macro-financial accounts of various economic sectors could be perceived through an analytical framework, including the private, public, banking and other external sectors in an open economy.

First developed in the International Monetary Fund (IMF) based on the work of some researchers like S.Alexander and J.J.Poles in the 1950's, this macroeconomic and macro-financial analysis is a standard accounting framework that provides a diagnosis of the economic and financial situation of different countries, either during consultations and negotiations for the implementation of Short-term financial support or a structural adjustment program. The interrelations between the aggregates traced in this accounting framework are based on the three balance of payments approaches considered by the IMF as the most important document for its analysis: the approach of internal absorption of the balance of payments, the fiscal approach to the balance of payments and the monetary approach to the balance of payments.

\section{Literature Review}

\subsection{Historical Context}

This approach was first developed by the F.M.I. for the statistically poorly equipped underdeveloped countries. It presents a simple relationship between the money supply and the balance of payments (POLAK, 1957). It was thouroughly developed by R. MERDELL (1968) and Franklin and JOHNSON (1976). Therefore, it was considered as a very important document in the analysis of the external imbalance for several years.

The emergence of this approach is linked to two characteristic changes of the 1970s: Historically, the collapse of the BRETTON WOODS system and the imbalances in payments balances after the first oil shock; and theoretically, the 
affirmation of monetarism as an essential framework of economic analysis.

Three characteristics of the monetary approach could be named: Firstly, it is an automatic equilibrium theory. Secondly, it focuses on the balance of official regulations (In the HUME's analysis, capital flows was not considered). Finally it is established around the idea that money is the center of the adjustment process. That is to say an imbalance in the balance of official settlements in fixed exchange rates or a modification in the exchange rate in flexible changes as a consequence of the mismatch between supply and demand for money allows restoring the balance.

In addition to encouraging a new understanding of a country's international financial imbalances, Polak's model also pointed out the measures that the IMF could recommend to countries in order to correct their imbalances (MOHSINE KHAN, - Middle East and Central Asia of the IMF).

According to Milton Friedman, the strength of a theory lays in its predictive ability and simplicity, in case it is as efficient as competing models and requires less information. The Polak model was known due to its simplicity. It uses only four equations. In other words, it is considered as a realistic model for numerous reasons, and most importantly, because of the scarcity of economic data and models in the early post-war years. Only a model limited to a few important variables can be generalized for all countries. In the same way, the economic policy should focus on a variable that could be controlled by the authorities to influence the balance of payments - in this case the creation of domestic credit.

The model shows that in a small open economy with a fixed exchange rate, the authorities do not control the money supply. Indeed, any expansion of credit beyond the limit allowed by the growth of national income causes a deficit in the balance of payments, a decrease of official reserves and deterioration of the money supply.

Under the fixed exchange rate regime, the balance of payments, or the variation of foreign exchange reserves in the banking system, reflects the orientation of the monetary policy. For the balance of payments to be stablized, the monetary authority must act by strengthening direct management instruments such as credit and interest rates, or indirect instruments based on the market.

In its highly simplified version, in fixed exchange (which is the case for many developing countries), the model can be reduced to the following equations:

- Production is fixed at a determined level according to the potential of the country:

$$
Y=Y^{\prime}
$$

- Domestic prices $(\mathrm{P})$ are fixed by the law of one price in the same level of international prices $(\mathrm{P} *)$, after being converted by a fixed exchange rate:

$$
P=e . P^{*}
$$

- The Money Demand (Md) depends on national income, assuming that the velocity of money $(\mathrm{k})$ is stable:

$$
M . d=k . P^{*}
$$

- Money supply (MM) includes the credit to the economy (C), which means the outstanding credit to the budget, the outstanding credit to private agents, and the official reserve's stock (R):

$$
M o=C+R
$$

- Finally, money supply and demand are necessarily equal:

$$
M o=b n
$$

By elimination, the POLAK model establishes a direct relationship between credit to the economy and the level of official reserves:

$$
R=k . P . Y^{\prime}-C
$$

Since production and prices are fixed, this equation shows that an increase in domestic credit leads directly to a drop in official reserves.

\subsection{The Consequences of the Monetary Approach to the Balance of Payments}

The monetary approach presents some issues. First issue is the assumption of small price taker country. Then there is the rejection of any sterilization action on the reserves. Finally, it seems inconceivable to correct the gap between the desired stock and the offered money supply over a long period of time. Furtheremore, the fact of avoiding mentioning partial balance makes it more difficult to identify the causes of the imbalance. The main idea is that any imbalance in the balance of payments is monetary (H. JOHNSON). The balance of the global balance therefore reflects the imbalance of the currency market. 


\subsection{Reviews about the Monetary Approach to the Balance of Payments}

The monetary approach to the balance of payments can be questioned. When it was first conceived in the 1950's, it reflected the former situation of the world economy. Although there was no mentioning of internal capital market, external capital markets and foreign exchange market (the exchange rate $\mathrm{Y}$ is assumed to be fixed).

This theory also supposes the constancy of money velocity, and the predictability of its variation. This assumption seems reasonable when economies grow more or less steadily. But it becomes highly debatable when economies are submitted to important shocks or large reform programs, like the structural adjustment programs.

The parity of purchasing power is supposed to be verified, which implies that the evolution of the money supply has no influence on prices or on the exchange rate; Nominal prices and wages are assumed to be perfectly flexible. Strangely, the model also ignores the impact of indebtedness; it is difficult to specify the time horizon for returning to stability without integrating this dimension.

Finally, this theory too often leads to reduced impact of real shocks (flows, goods and services shocks), while they have an important place in developing countries such as a sudden variations in produced quantities or in the prices of raw materials.

However, criticizing the theory should not lead us to ignore the importance of reading the balance of payments from the bottom. Thus, the balance of payments can be considered as a reflection of permanent reallocations of resident and non-resident agents. This idea has gradually become more evident as obstacles to the international mobility of capital have been reduced.

\subsection{Application of the Monetary Balance of Payments Approach to Developing Countries}

To clarify this point, the attention will be focused on the shortcomings of the Keynesian theory and its application on the economy of developing countries, which are struggling with balance of payments and Inflation. Indeed, according to the Keynesian theory, economic growth (increase in income) leads to deterioration in the balance of payments, due to the increase in imports related to exports. But this analysis neglects the influence of the demand for money on the supply of exports and on the demand for imports and on the international assets flows.

On the other side, according to the Keynesian model, the expansion of domestic credit leads to an improvement of the balance of payments by stimulating investment and increasing productivity. As a result, it leads to a drop in domestic prices compared domestic prices from other countries. This situation helps achieving an improvement in the current account through the substitution of domestic and foreign goods in domestic and international markets.

Finally, the Keynesian analysis cannot be applied to developing countries when it comes to the role of money.

Myint (1965) is one of the authors who adopted this position, and according to him autonomous spending may have no effect on national income in developing countries for two reasons; the first one, is that the demand for money in these countries is completely inelastic to interest rates, so any fiscal policy or other exogenous variation in expenditure leads in changes on interest rates only. Moreover, the level of production is constrained by the supply of factors, so the aggregate expenditure has no effect on real income. The other reason is that as for the monetary approach, it states that the increase in international reserves is positively linked to the income elasticity of the money demand and negatively to the increase in domestic credit, contrary to the Keynesian theory. This approach seems to be better adapted to developing countries. Indeed, these economies are responsive to the assumptions of this approach.

First, inflation in these countries can be largely explained by the supply of money (monetary expansion caused by financing the government deficit). Secondly, they are small open economies with a fixed exchange rate, a small organized capital market with largely autonomous flows, and currency holding for transaction reasons, so not sensitive to interest rates.

Finally, the stock of money in these countries is endogenous. According to the monetary approach, this endogeneity is caused by the effect of the balance of payments through changes in net foreign assets relatively to the monetary liabilities of the central bank.

\section{Method}

\subsection{The Model}

In this paper we will use the Polak model on the morrocan data in order to study the more significant equations and variables. 
The model is a system of simultaneous equations:
(1) $M M=k \cdot Y+c$
(2) $M=m . Y+c$
(3) $X=n . Y+c$
(4) $M M=\triangle R+C R$
(5) $B C=X-M$
(6) $\Delta R=B C+F$

MM : Money supply

$\mathbf{Y}:$ Gross domestic product

$\mathbf{M}:$ Imports

$\mathbf{X}:$ Export

$\Delta \mathbf{R}:$ Foreign exchange reserves's variation

CR : Domestic credit

BC : Balance of trade

F: Payments balance

The first equation links the money supply to income $\mathrm{Y}$ (with a fixed link where $\mathrm{k}$ represents the inverse of the velocity of money).

In the second equation, imports $\mathrm{M}$ are linked to income $\mathrm{Y}$ by the marginal propensity to import (which is constant) $\mathrm{m}$.

The third equation expresses the equality between the demand and the supply of money. Supply of money varies when the foreign exchange reserves $\mathrm{R}$ and the domestic credit $\mathrm{CR}$ change. This equation is important because the change in foreign exchange reserves $\Delta \mathrm{R}$ appears as a balance on the money market.

The fourth equation defines the current balance and the last equation is the equilibrium equation of the balance of payments.

The fundamental result of the monetary approach is the following: Any imbalance between the supply and the demand for money results in the imbalance of the global balance.

In order to estimate the model we will use the Double Least Squares method because of the consistency of its results to define the most significant equations.

After correcting the stationarity of the series, two tests have been applied on the model:

Autocorrelation of errors: the durbin Watson test confirmed that none of the equations contain autocorrelation of errors.

Table 1. Autocorrelation of errors

\begin{tabular}{cc}
\hline Equation & DW \\
\hline$(1)$ & 1,50109 \\
$(2)$ & 1,6169 \\
$(3)$ & 1,608455 \\
\hline
\end{tabular}

White test: the results of the test come up with a homoscedaticity which means that the explanatory variables don't have any effect on the squared residual.

Table 2. Durbin Watson

\begin{tabular}{cc}
\hline Equation & Probability of F (5\%) \\
\hline$(1)$ & 0,971083 \\
$(2)$ & 0,439504 \\
$(3)$ & 0,109774 \\
\hline
\end{tabular}




\subsection{Estimation}

(1) $M M=0,434629 Y+19159,95$

(2) $\quad M=-0,013141 Y+6533,06$

(3) $\quad X=1.447707 Y+77268,32$

The fisher's test comes up with the conclusion that only the equation connecting export to the gross domestic product is significant $\left(\mathrm{F}_{\mathrm{c}}=6,0150>\mathrm{F}_{\mathrm{th}}=4,19597171\right)$.

Table 3. Fisher test

\section{Results}

\begin{tabular}{ccc}
\hline Equation & $\mathrm{F}_{\mathrm{c}}$ & $\mathrm{F}_{\text {th }}$ \\
\hline 1 & 1,6812 & 4,19597171 \\
2 & 0,0178 & 4,19597171 \\
3 & 6,0150 & 4,19597171 \\
\hline
\end{tabular}

Based on the results of the estimation we concluded that in order to fill the Moroccan balance of payment gap, the country has to improve exports, which is consistent with the economic theory and reality.

As for the rest of developing countries, the exportable offer is very weak comparing to the imports. In despite of the improvement in the structure of exports to relatively better-valued products, such as "the new global business lines", the structure is still largely made up of low value-added products. In addition, $45 \%$ of the export rate is composed of "low-valued" traditional products. The reduction of the trade deficit can only be achieved through the development of an abundant and competitive supply that not only fills the needs of the domestic market but also stimulates sales in foreign markets.

The most important problem in stimulating an exportable offer with high added value is the competitiveness of Moroccan products. This element can only be acquired by optimizing the costs of production factors and by training a highly skilled workforce. Efforts must be focused on mobilizing an additional competitive exportable offer and adapting existing supplies to market requirements. For this reason, the Moroccan department of foreign trade had elaborated in 2009 a development strategy in order to promote exports called "Maroc Export Plus". Its main goal is to triple the export of goods and services by 2018.

The results seem to be optimisic since the last data from the department of financial forecasts shows a strong dynamism of exports since external demand increases thanks to global businesses in Morocco.

The leading sectors Automotive, aerospace and electronics, contribute the most to exports growth. According to the DEPF, the automotive sector exported, at the end of July 2016, the equivalent of 32.2 billion Dhs.

The Moroccan exportable offer grows also by aeronautics. Their export increased by $9.3 \%$ to 5.1 billion Dhs. The increased trend is maintained by electronics, whose exports climbed to $4.4 \%$ to reach 5 billion Dhs. This expansion denotes Morocco as regional industrial hub. Automotive giants as Renault and Peugeot and aeronautics as Bombardier, Boeing, Airbus settled in Morocco and confirmed the new vocation of the Kingdom.

\section{References}

Abdellah, El. M. (1983). Monnaie, prix et balance des paiements, Etude sur le Maroc.

Albert, O. O. (1999). Economie monétaire internationale, édition ESTEM.

Bank Almaghrib(2004). Bulletin trimestriel, $N^{\circ} 101$ September.

Direction de la balance des paiements, Banque de France, la balance des paiements : Établissement et présentation, Eurosystème.

Gilles, M. (2010). Institut bancaire et financier international, Document pédagogique: l'équilibre macroéconomique et macro-financier en économie ouverte un cadre comptable d'analyse, Eurosystème.

Jacques, J. P., \& James, M. B. (2016). Economic Theory and Financial Policy: Selected Essays of Jacques J. Polak.

James, L. R. (2008). Un modèle élégant en héritage, Finances \& Développement.

Jean, M. (1992). Monnaie et banques en Afrique francophone, EditionEdicef. 
Marc, R. (2006). Cadre comptable et programmation financière, Université Paris Dauphine.

Marc, R., \&Baptiste, V. (2003). La balance des paiements, Edition La Découverte.

Marc, R. (1991). Dette extérieure et ajustement structurel EditionEdicef.

Ministère de l'industrie, du commerce et de la nouvelle technologie, Département du commerce extérieur (2012). Analyse des échanges commerciaux du Maroc : principaux déterminants du déficit commercial (1998-2011).

Ministère des Finances, Direction des Etudes et des Prévisions financières (1996). Impacts du Programme d'Ajustement Structurel Document de travail $\mathrm{n}^{\circ} 13$.

Ministère des Finances, Direction des Etudes et des Prévisions financières (2008). La politique commerciale extérieure du Maroc : Une esquisse d'appréciation.

Nations Unies (2010). Bilan commun de pays : Maroc.

Officedes changes (2009). Balance des paiements.

\section{Appendix A: Data}

Source: WORLD BANK

(1980-2016)

\begin{tabular}{|c|c|c|c|c|c|c|c|c|}
\hline obs & $\mathbf{B C}$ & CR & $\mathbf{M}$ & MM & $\mathbf{F}$ & VR & $\mathbf{X}$ & $\mathbf{Y}$ \\
\hline 1986 & -16127.58 & 31215.14 & 44269.93 & 29788.51 & 14700.95 & -1426.632 & 28142.34 & 12998.8 \\
\hline 1987 & -17659.62 & 36939.45 & 47182.48 & 3553 & 16254.92 & -140 & 2952 & 207110.8 \\
\hline 1988 & -157 & 437 & 47865.16 & .49 & 13140.01 & .390 & .76 & 32.7 \\
\hline 1989 & -101 & .43 & .14 & 4 & 093 & .440 & 61 & 6.9 \\
\hline 1990 & -11 & 567 & 490 & 55 & 3 & -175 & .23 & 57.0 \\
\hline 1991 & -108 & 64937.72 & .03 & 6 & 979 & -10 & 409 & 6.3 \\
\hline 1992 & -102 & 721 & 510 & 757 & 139 & 364 & 40799.06 & 271 \\
\hline 1993 & -114 & 77243.00 & 562 & 79729.38 & 139 & 248 & 44770.80 & 40.1 \\
\hline 1994 & -6593.041 & 84026.00 & 61053.70 & 86766.85 & 9333.890 & 2740. & 54460.66 & 291870.1 \\
\hline 1995 & -125 & 926 & 69 & 7.35 & 13662.44 & 50 & 5.60 & 298777.6 \\
\hline 1996 & -9790.268 & .00 & 72400.48 & 10 & 12 & 3 & .21 & 1.6 \\
\hline 1997 & -12641.62 & 108782.0 & 77310.86 & 116927.1 & 8521.200 & 076 & 64669.24 & 332 \\
\hline 1998 & -196 & 5.0 & 87 & 12 & 72 & 64 & 6 & 9.2 \\
\hline 1999 & -12759.88 & 130921.0 & 83743.42 & 65.0 & 4082 & 56 & .53 & 1.3 \\
\hline 2000 & -11108.69 & 145462.0 & 88480.74 & 219.0 & 4952.500 & 4756.989 & 77372.06 & 6.6 \\
\hline 2001 & -189 & 166 & 10 & 16 & 0 & -64 & 79 & 7.3 \\
\hline 2002 & -11150.50 & 176690.0 & 95610.25 & 179276.1 & -2919.700 & 2586.106 & 9.75 & 365184.4 \\
\hline 2003 & -136 & 13.0 & .4 & 8.1 & -792.4000 & 79 & .31 & 9.1 \\
\hline 2004 & -141 & 282797.0 & 1080 & 285 & -62.40 & 23 & 00 & 5.0 \\
\hline 2005 & -12539.00 & 291976.0 & 115673.0 & 19.2 & 482.1000 & 16043.21 & 34.0 & 20.0 \\
\hline 2006 & -125 & 00.0 & 1244 & 2.8 & 3886.500 & 17 & 61.0 & 392574.0 \\
\hline 2007 & 464.0000 & 298496.8 & 126173.0 & 336 & -207 & 3775 & 1266 & 21.0 \\
\hline 2008 & -501.0000 & 315950.3 & 134297.0 & 32554 & -14127.80 & 9590.2 & 13 & 2.0 \\
\hline 2009 & -9149.000 & 326907.0 & 143805.0 & 351168.7 & -12155.90 & 24261 & 6.0 & 463778.0 \\
\hline 2010 & -148 & 343358.3 & 1579 & 30.9 & -598 & 1837 & 14 & 8.0 \\
\hline 2011 & -11080.00 & 385694.9 & 173206.0 & 408527.9 & -5771.800 & 22833.06 & 162126.0 & 500525.0 \\
\hline 2012 & -6371.000 & 452385.8 & 187337.0 & 477926.3 & -7912.300 & 25540.42 & 180966.0 & 65.0 \\
\hline 2013 & -25131.00 & 560999.9 & 215488.0 & 577532.0 & -437.0000 & 16532.08 & 190357.0 & 553959.0 \\
\hline 2014 & -37578.00 & 679481.5 & 241762.0 & 668511.8 & 39114.70 & -10969.70 & 204184.0 & 584909.0 \\
\hline 2015 & -531 & 737974.1 & 227225.0 & 73 & 44041.90 & -4385.271 & 174036.0 & 612741.0 \\
\hline 2016 & -32387.00 & 788093.7 & 234713.0 & 788121.2 & 37193.70 & 27.50650 & 202326.0 & 635277.0 \\
\hline
\end{tabular}




\section{Appendix B: Double least squares estimation}

TSLS dmm c y@y cr f

Dependent Variable: DMM

Method: Two-Stage Least Squares

Date: 06/11/17 Time: 13:17

Sample (adjusted): 19812010

Included observations: 30 after adjustments

Instrument list: DY CR F

\begin{tabular}{crcrr} 
Variable & Coefficient & Std. Error & t-Statistic & \multicolumn{1}{c}{ Prob. } \\
C & 19159.95 & 7074.444 & 2.708332 & 0.0114 \\
DY & 0.434629 & 0.335194 & 1.296648 & 0.2053 \\
R & 0.056645 & Mean dependent var & & 25277.76 \\
R-squared & 0.022954 & S.D. dependent var & & 29209.26 \\
egression & 28872.09 & Sum squared resid & & $2.33 \mathrm{E}+10$ \\
c & 1.681295 & Durbin-Watson stat & & 1.501097 \\
& 0.205337 & & &
\end{tabular}

TSLSdm c y@y cr

Dependent Variable: DM

Method: Two-Stage Least Squares

Date: 06/11/17 Time: 13:22

Sample (adjusted): 19812010

Included observations: 30 after adjustments

Instrument list: DY CR F

\begin{tabular}{crcrr}
$\quad$ Variable & Coefficient & Std. Error & t-Statistic & \multicolumn{1}{c}{ Prob. } \\
C & 6533.068 & 2078.301 & 3.143465 & 0.0039 \\
DY & -0.013141 & 0.098472 & -0.133444 & 0.8948 \\
DY & 0.000636 & Mean dependent var & 6348.102 \\
ed R-squared & -0.035056 & S.D. dependent var & 8337.050 \\
regression & 8481.924 & Sum squared resid & $2.01 \mathrm{E}+09$ \\
- & 0.017807 & Durbin-Watson stat & 1.616909 \\
\hline
\end{tabular}

TSLSdm c y@y cr f

Dependent Variable: $\mathrm{X}$

Method: Two-Stage Least Squares

Date: 06/11/17 Time: 13:22

Sample (adjusted): 19812010

Included observations: 30 after adjustments

Instrument list: DY CR F

\begin{tabular}{|c|c|c|c|c|}
\hline Variable & Coefficient & Std. Error & t-Statistic & Prob. \\
\hline $\mathrm{C}$ & 77268.32 & 12458.23 & 6.202189 & 0.0000 \\
\hline DY & 1.447707 & 0.590284 & 2.452561 & 0.0207 \\
\hline R-squared & 0.176835 & Mean dependent var & & 97646.15 \\
\hline Adjusted R-squared & 0.147436 & S.D. dependent var & & 55065.41 \\
\hline S.E. of regression & 50844.30 & Sum squared resid & & $7.24 \mathrm{E}+10$ \\
\hline F-statistic & 6.015054 & Durbin-Watson stat & & 1.608495 \\
\hline Prob(F-statistic) & 0.020676 & & & \\
\hline
\end{tabular}

\section{Copyrights}

Copyright for this article is retained by the author(s), with first publication rights granted to the journal.

This is an open-access article distributed under the terms and conditions of the Creative Commons Attribution licensewhich permits unrestricted use, distribution, and reproduction in any medium, provided the original work is properly cited. 